\title{
Importance of Communication During Change: A Case of the Municipality of Vlora
}

PhD Cand. Rezarta Hasanaj

Department of Business, University of Ismail Qemali, Vlore, Albania

Prof. Asoc. Mimoza Manxhari

Department of Management, Faculty of Economics, University of Tirana

\begin{abstract}
Public sector organizations are often perceived as resisting change. One of the most important changes in Albania is the implementation of the administrative -territorial reform. Literature suggests that one of the critical factors in all change, and one of the toughest issues in an organization, which brings the frequent failure of change efforts, is communication. This paper, presents the importance of effective communication in change management in public sector.
\end{abstract}

Keywords: change; change management; change in public sector; communication and change

\section{Introduction}

Public sector organizations are often perceived as resisting changing. One of the most important changes in Albania is the implementation of the administrative -territorial reform. Thus, it is in a time of change. Literature suggests that one of the critical factors in all change, and one of the toughest issues in an organization, which brings the frequent failure of change efforts, is communication. This paper, presents the importance of effective communication in change management in public sector.

In addition, it is regular and effective communications that reduces levels of uncertainty and reduces the impact of resistance in an organization. A new strategy, system will not succeed, without organizational adoption; thus, communication is essential to the effective implementation of organizational change (Schweiger and Denisi, 1991). DiFOnzo suggests, poorly managed change communication results in rumors and resistance to change, overstating the negative aspects of the change. The model of planned organizational change displays the importance of communication. Robertson et al. , 1993). In other words, success of change is dependent on the ability of the organization to change the behavior of its employees. Thus, communication about the change is important, and information to these employees is vital. Conclusion about the importance of communication in organizational change is demonstrated and agreed on (Lewis, 2006).

\section{COMMUNICATION AND CHANGE}

\section{A. Communication}

Those working on reforms are aware that implementing change can be difficult. It has often been seen that government ministries disagree on policy, the private sector may resist changes to their working environment, while the public may be wary of any policy that adds to their financial or social burden. Communication is an action between at least two persons, where messages are delivered, received and reacted to among participants. It proves to be the most significant tools in social life and business management.

The importance of communication is discussed by many authors, such as Kotter and Schlesinger, during a change process. Kotter and Schlesinger argued that one of the common ways to overcome resistance to change is to inform people about it in advance. Employees need to be informed on when the change will take place, how it will be implemented, what is anticipated of them, how they will be affected from the change in their jobs, and how the company will sustain and motivate them to be more dedicated to the change. In addition, state that employees have a need for assurance in their working 
environment (Gilgeous and Chambers, 1991). What this means is that, it is critical for managers to be able to predict the outcome of the change and guarantee that every employee has reasonable information of why, what and how the change is put into practice. Early communication can decrease pessimism and uncertainty, minimize rumors before they spread throughout the whole organization.

\section{B. Communicating Change}

Communication is generally at the core of any successful reform initiative. It is recommended by change management literature that communication is important to the accomplishment of change programs (Caruth \& Rachel, 1985). According to Lewis, communication and organizational change are processes that are connected together. Communication is used every day by employees at the work place. Deresky, mentions in his work that managers use communication to organize activities, to motivate people, to inform and to discuss opportunity or plans. Communication incorporates timing, message content and its methods. Managers should understand that effective communication is the key to implement change and make it a success. Barrett disputes that where there is not a reliable communication, the hearts and minds of the employees are never captured. Public administrators can be seen as the link between the public and policy makers. To operate effectively, public administrators should take into consideration the public's needs and worries. According to Beckman, good communication skills can assist public administrators discuss with members of the public about different issues which then be discussed with policy makers. Whereas the policy makers may not always act precisely as the public would like, the community can feel content that policy decisions take place when information flows freely. However, during an administrative -territorial reform it is important to lower resistance of employees with effective communication. If employees are aware of where they exactly, how they are effected and what they are expected to do, could help during a change process. Good communication would not only help employees but also the public with the reform.

\section{Effective Communication}

Burke suggests that during a major change effort communicating too much is difficult. While Vuuren, Klandermans at all, argue that rich, open and honest communication, which appears in management's readiness to answer every question asked about any planned changes. Clampitt, DeKoch at all, state that in a rather unstructured change project, employees want to know where their position is and what will occur next more than ever, or else important procedures and phases may be disregarded and resources may be allocated for completing less important actions. Thus, that one factor essential for the success of change is the ability to communicate to employees the kind of changes will cause as the tasks and working environment. In addition, Kaufman suggests that the more open and detailed communication starts, the more trust is likely to build between different parties implicated in the change (Kaufman 1992).

Furthermore, communication is an important tool constructing common understanding of organization's goals and direction. What communication aims is therefore, to provide the necessary information to employees while answering the following questions: what the change is about: why is it started, what parts of the institute are involve in change and what are its objectives and schedules. Kotter suggests that during change lacking of communication does not let loose the real power of setting goals, envisioning, and planning.

In addition, Kotter suggests that the most effective method of communication is to use as many different approaches to communicate, and to repeat the message several times in every probable occasion, official or unofficial. According to Kotter (1996,), He also suggests that the main reason communication is not unsuccessful is simply because not enough effort is put in doing it. It is often assumed that the vision and plan that top management or the group of change has worked on for months can be clear and easily digested from the rest of the employees in a period of time the planned change and the heart of it. Kotter 1996,)

\section{COMMUNICATION STRATEGY}

According to Klein, the communication strategy should match with the general stages of the change process and the appropriate related information necessary. Taking into consideration Lewin's change model, Klein has acknowledged the objectives and communication needs for each stage of the change process.

\section{- Communicating during the unfreezing stage}

The key communication objective in this stage is to get ready the staff and the organization for the change. Resistance will increase at the same rate with change. In other words, the more resistance means the bigger the change. However, this 
resistance could be lowered if the communication strategy is designed to account for the early resistance (Klein, 1996). Hi suggests that in order to prepare the organization for the change, it is important to communicate why there is a need for change and what is going to happened. In addition, ff the change is an organization-wide change; the CEO of the company should be the first to communicate the message. Even though written communication followed by question and answers gathering has been confirmed to be an effective way of communication; however, face-to-face communication is key in this stage (Klein, 1996).

- Communicating during the move stage

During the implementation of change, there is a lot of organizational activity. In this stage there is a high level of uncertainty due to the fact that most of employees are not directly implicated in the change process and are not aware of exactly what is happening. Hence, communication in this stage is very significant and has aims to: provide with detailed and accurate information of what is happening to the staff not directly involved in change implementation; to provide information about their roles in the change process to the staff involved in the change process, in addition to provide the necessary information about how the change will affect them including their new roles and responsibilities; and finally to clear the area from any misinformation that flows through the organization "Because the change is beginning to have more tangible outcomes and some organizational impact, the communication should have a more specific character than in the first stage (Klein, 1996).

\section{- Communicating during the refreezing stage}

The main objectives during this stage are to construct structures and processes that hold up the new ways. In addition, communication should be focused on responding to employees' questions concerning effectiveness, rewards, relationship roles and control. In this stage, the responsibility of communicating with employees is down the hierarchy to supervisory management. The information flow should be incessant, concrete and multidirectional, so that employees have adequate understanding of the personal implications the change has. Because of the expected misunderstandings that may take place in this stage, communication should primarily concentrate on making public the success of the change and spread the word to employees (Klein, 1996).

\section{RESEARCH METHODOLOGY}

The research design employed for this study involved structured interviews of fifteen employees over the last three years. For the purpose of this study, the target population includes of individuals employed at all levels within the municipality of Vlora.

Within the municipality, the importance of communication as viewed by the interviewees is reflected in the following comments:

On a general level, communication within municipality is not effective due to the fact that to us, employees, not much is communicated...

There needs to be an open line of communication from top to bottom. The information we receive is manly from rumors than we do from bosses and that is sad. You need to give employees an overview of what is happening.

We need to know facts. I do not believe that all information is presented in an open manner. Quite often one gets the feeling that decisions already made are being sold or imposed to you. So I don't think this workplace fosters open expression or opinions if you have a different point of view from those presented to you.

In addition to these comments, it was also mentioned by a few of the employees that they felt that the issue of openness and trust between units within Municipality, as well individual employees, was being worn due to poor communication.

I cannot tell you how important communication is and my experience has taught me that when communicated is not truthfully then you do not trust ... If your communication is opened and honest, change can be easy.

The issue of communication being a time consuming process was echoed by 'Ana who asserted that: 
Communication needs to be at all times. Frequently people with my experience are very aware of changes that are going on a long time before it is officially spoken which leads to a lot of rumors and misinformation. Thus, timely communication is essential.

Also, some employees clearly state that there was a lack of information about the daily activities within municipality due to the big gap between management and lower level employees and that most employees were not taking part in the change process.

With regard to the subject of communication effectiveness within the municipality, the following conclusions were drawn:

Objectives were not clearly communicated in an open way.

Communication within municipality was not very effective in that it did not provided sufficient information and did not allowed much discussion when meetings were held.

Most employees felt less positive about how well their manager was informing them about municipality matters.

In general communication in municipality was viewed as being helpful.

\section{CONCLUSION}

Effective communication can be the key to a change process. It can help employees get engage in the change process as well make them aware of the vision and objectives related to the change. In turn it helps organizations to persuade employees that the status quo is no longer satisfactory and motivates them to support the new state. Thus, in order to implement change successfully and maximize the productivity of persons involved in the change process, communication should be viewed by organizations as a key lever during change.

\section{References}

[1] Barrett, D. J. 2002). "Change communication: using strategic employee communication to facilitate major change". Corporate Communications: An International Journal, Vol. 7. 4.

[2] Brown, M. , \& Cregan, C. 2008). "Organizational change cynism: the role of employee involvement". Wiley InterScience.

[3] Bauner, R. 2016). http://blogs. worldbank. org/category/tags/communication-reformCommunication for Reform 10 reasons to apply for World Bank-Annenberg Summer Institute, Retrieved March 07, 2016.

[4] Caruth, J., Middlebrook, B. \& Rachel, F. 1985). "Overcoming resistance to change". Advanced Journal of Management, Vol. 50, 3

[5] Clampitt, P. G., DeKoch, R. J. and Cashman, T. 2000). "A strategy for communicating about uncertainty". Academy of Management Executive. Vol. 14 No. 4, pp. 41-57.

[6] Daly, F. , Teague, P. and Kitchen, P. 2003). "Exploring the role of internal communication during organizational change", Corporate Communications: An International Journal, Vol. 8 No. 3, pp. 153-62.

[7] Deresky, H. 2000). "International management: managing across borders and culture " 3rd Ed. New Jersey: Prentice Hall

[8] De Ridder, J. 2003). "Organisational communication and supportive employees". Human Resource Management Journal. Vol. 13. 4.

[9] DiFonzo, N. , \& Bordia, P. 1998). "A tale of tow corporations: Managing uncertainty during organizational Change". Human Resource Management, 295-303.

[10] Francis, D. 1989). "Organisational Communication" Corporate Communications: An International Journal, Vol. 5. 4.

[11] Gilgeous, V. \& Chambers, S. , (1999). "Initiatives for managing resistance to change". Journal of General Management. Vol. 25. 2, 1999 
[12] Hartley, J., Klandermans, B. and van Vuuren, T. Eds) Job Insecurity: Coping with Jobs at Risk. Sage Publishers: London, pp. 79-103.

[13] Kaufman, R. 1992). Change Management Communication: Laying the ground work for a successful communication strategy. The Parker Avery Group. Retrieved Nov. 5, 2016

[14] Klein, S. M. , (1996). "A management communication strategy for change". Journal of Organizational Change Management. Vol. 9. 2

[15] Kotter, J. P. 1995). “Why Transformation Efforts Fail”. Harvard Business Review. Vol. 73. 2) 2: 59-67.

[16] Kotter, J. P. 1996). Leading Change. Harvard Business School Press.

[17] Lewin, K. 1951). Field theory in social science. Harper and Row: New York

[18] Lewis, K. 1999). "Disseminating information and soliciting input during planned organizational change: implementers' targets, sources, and channels for communicating". Management Communication Quarterly, Vol. 13. 1) pp. 43-75.

[19] Lewis, K. 2006). "Employee perspectives on implementation communication as predictors of perceptions of success and resistance". Western Journal of Communication. 70 (1), 23-46.

[20] Tannenbaum, R. 1971), "Organisational change has to come through individual change" Innovation Journal. Vol. 23 (1) pp. 36-43.

[21] Scheweiger, D. , \& DeNisi, A. 1991). "Communication with employees following a merger: A (longitudinal field experiment". Academy of Management Journal. 110-135.

[22] Vuuren, T., Klandermans, B. , Jacobson, D. and Hartley, J. 1991), "Employees' reactions to job insecurity", Academy of Management Review, Vol 20 (3), p. 514-586. 